\title{
Cobalt Source Calibration
}

by

H. M. Rizvi

Westinghouse Savannah River Company

Savannah River Site

Aiken, South Carolina 29808

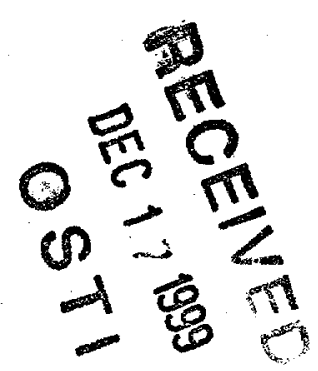

DOE Contract No. DE-AC09-96SR18500

This paper was prepared in connection with work done under the above contract number with the U.S. Department of Energy. By acceptance of this paper, the publisher and/or recipient acknowledges the U.S. Government's right to retain a nonexclusive, royalty-free license in and to any copyright covering this paper, along with the right to reproduce and to authorize others to reproduce all or part of the copyrighted paper. 


\section{DISCLAIMER}

This report was prepared as an account of work sponsored by an agency of the United States Government. Neither the United States Government nor any agency thereof, nor any of their employees, makes any warranty, express or implied, or assumes any legal liability or responsibility for the accuracy, completeness, or usefulness of any information, apparatus, product or process disclosed, or represents that its use would not infringe privately owned rights. Reference herein to any specific commercial product, process or service by trade name, trademark, manufacturer, or otherwise does not necessarily constitute or imply its endorsement, recommendation, or favoring by the United States Government or any agency thereof. The views and opinions of authors expressed herein do not necessarily state or reflect those of the United States Government or any agency thereof.

This report has been reproduced directly from the best available copy.

Available for sale to the public, in paper, from: U.S. Department of Commerce, National Technical Information Service, 5285 Port Royal Road, Springfield, VA 22161

phone: (800) 553-6847

fax: (703) 605-6900

email: orders@ntis.fedworld.gov

online ordering: http://www.ntis.gov/ordering.htm

Available electronically at http://www.doe.gov/bridge

Available for a processing fee to U.S. Department of Energy and its contractors, in paper, from: U.S. Department of Energy, Office of Scientific and Technical Information, P.O. Box 62, Oak Ridge, TN 37831-0062

phone: (865)576-8401

fax: (865)576-5728

email: reports@adonis.osti.gov 


\section{DISCLAIMER}

\section{Portions of this document may be illegible in electronic image products. Images are produced from the best available original document.}


WSRC-TR-99-00303, Rev. 1

COBALT SOURCE CALIBRATION

H. M. Rizvi

October 5, 1999

Westinghouse

Savannah River Company

Aiken, SC 29808

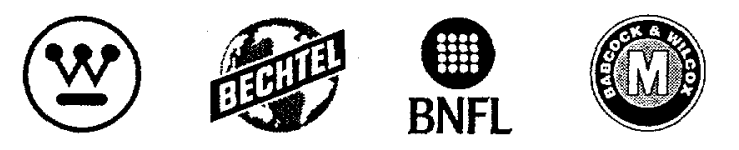


S. D. Fink

WSRC-TR-99-00303, Rev. 1

Page 2 of 10

COBALT SOURCE CALIBRATION

Author

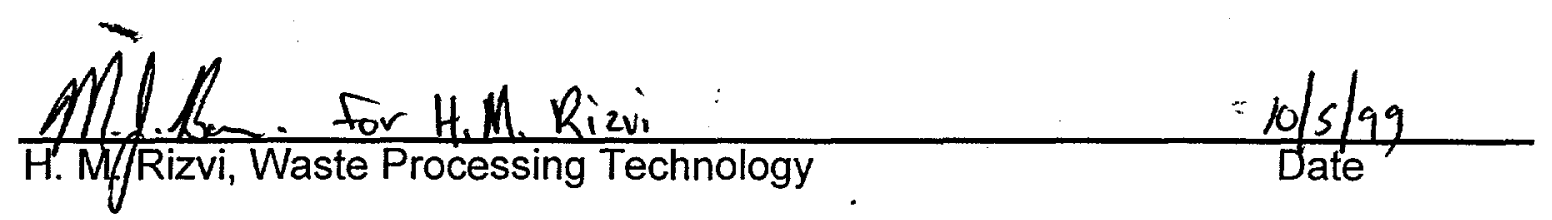

Design Check

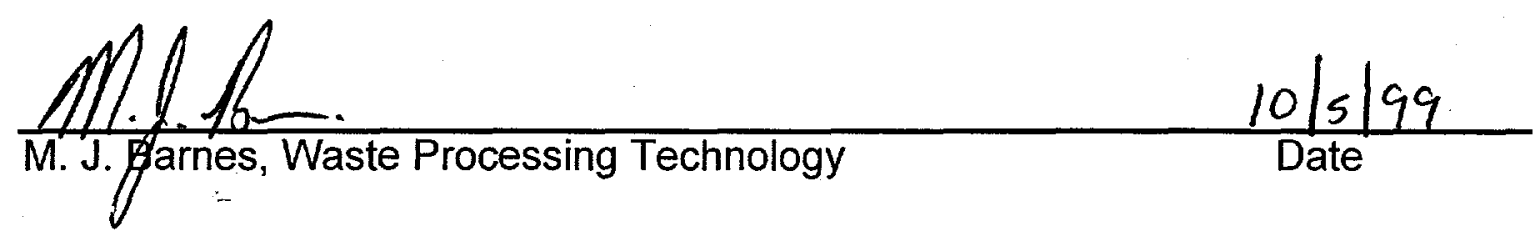

Approvals/Review
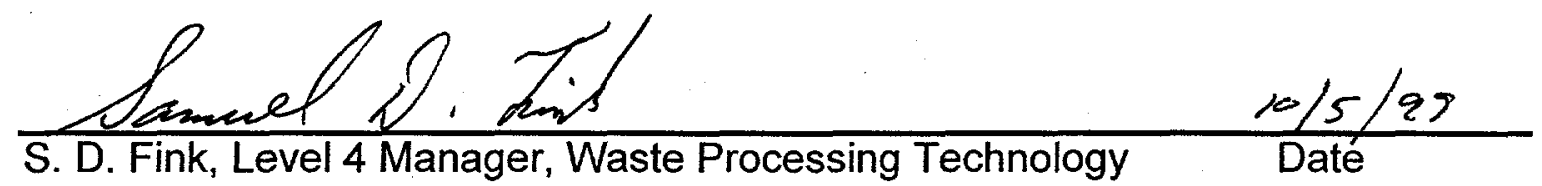

Darrel D. Walker

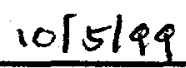

D. D. Walker, Waste Processing Technology

Date 


\subsection{Summary}

The data obtained from these tests determine the dose rate of the two cobalt sources in SRTC. Building 774-A houses one of these sources while the other resides in room C-067 of Building 773-A. The data from this experiment shows the following.

- The dose rate of the \#2 cobalt source in Building 774-A measured $1.073 \times 10^{5}$ $\mathrm{rad} / \mathrm{h}$ (June 17, 1999). The dose rate of the Shepherd Model $109 \mathrm{Gamma}$ cobalt source in Building 773-A measured $9.27 \times 10^{5} \mathrm{rad} / \mathrm{h}$ (June 25,1999$)$. These rates come from placing the graduated cylinder containing the dosimeter solution in the center of the irradiation chamber.

- Two calibration tests in the 774-A source placed the graduated cylinder with the dosimeter solution approximately 1.5 inches off center in the axial direction. This movement of the sample reduced the measured dose rate $0.92 \%$ from $1.083 \times 10^{5} \mathrm{rad} / \mathrm{h}$ to $1.073 \times 10^{5} \mathrm{rad} / \mathrm{h}$.

- A similar test in the cobalt source in 773-A placed the graduated cylinder approximately 2.0 inches off center in the axial direction. This change in position reduced the measured dose rate by $10.34 \%$ from $1.036 \times 10^{6}$ to 9.27 $\times 10^{5}$.

\subsection{Introduction}

This testing used chemical dosimetry to measure the dose rate of a radioactive source. In this method, one determines the dose by the chemical change that takes place in the dosimeter. For this calibration experiment, I used a Fricke (ferrous ammonium sulfate) dosimeter. This solution works well for dose rates to $10^{7} \mathrm{rad} / \mathrm{h} .{ }^{1}$ During irradiation of the Fricke dosimeter solution the $\mathrm{Fe}^{2+}$ ions ionize to $\mathrm{Fe}^{3+}$. When this occurs, the solution acquires a slightly darker tint (not visible to the human eye). To determine the magnitude of the change in Fe ions, one places the solution in an UV-VIS Spectrophotometer. The UV-VIS Spectrophotometer measures the absorbency of the solution. Dividing the absorbency by the total time (in minutes) of exposure yields the dose rate.

\subsection{Experimentation}

This experiment calibrated two cobalt sources: the \#2 source in Building 774-A, and the Shepherd Model 109 Gamma Source in Building 773-A, Room C-067. For each source, the test included two different dose rate measurements. One measurement centered the quartz graduated cylinder while the other moved the graduated cylinder off-center.

\footnotetext{
${ }^{1}$ Bibler, Ned E. Calibration of Intense Co Gamma Ray Sources at the Savannah River Plant. May 1976. DP-1414.
} 


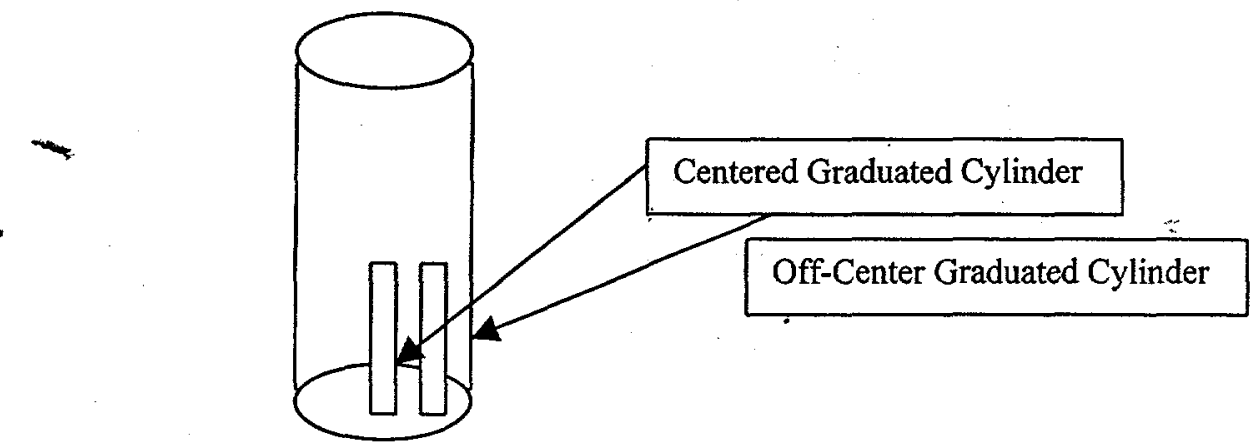

The off-center, and centered calibrations occurred separately in building 774-A. During calibration, the researcher lowered the quartz-graduated cylinder into the source for 2.5, 5.0, 7.5, and 10.0-minute time periods. Calibration of the centered and off-center graduated cylinder in the source in building 773-A occurred simultaneously. This calibration exposed the graduated cylinders to radiation for approximately $15,30,45$, and 60 -second time periods. After each exposure, the researcher poured the irradiated solution into a labeled glass vial. The researcher then rinsed the graduated cylinders with unirradiated Fricke solution, and refilled with unirradiated Fricke solution for the next measurement. I completed the following tests.

\begin{tabular}{|l|l|l|}
\hline \multicolumn{2}{|l|}{ Experiments } & Comments \\
\hline 1 & Calibration of 774-A Source Centered & \\
\hline 2 & Calibration of 774-A Source Centered & $\begin{array}{l}\text { Replicate of } \\
\# 1\end{array}$ \\
\hline 3 & Calibration of 774-A Source Uncentered & \\
\hline 4 & Calibration of 774-A Source Uncentered & $\begin{array}{l}\text { Replicate of } \\
\# 3\end{array}$ \\
\hline 5 & Calibration of 773-A Source Centered & \\
\hline 6 & Calibration of 773-A Source Uncentered & \\
\hline
\end{tabular}

\subsection{Results and Discussion}

\subsection{Calibration of Source in building 774-A Centered}

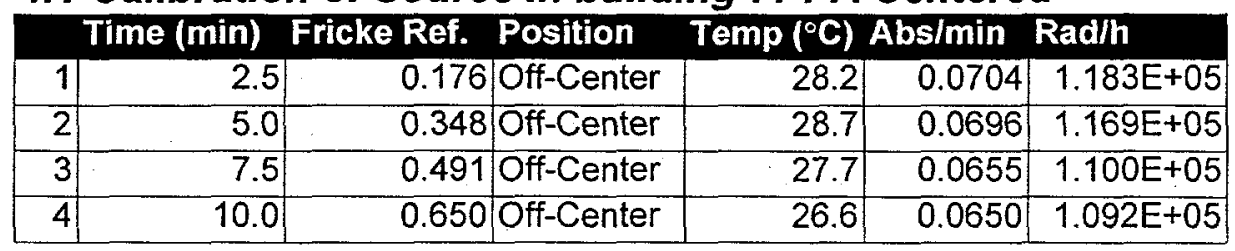

R-Square: 0.99883

Dose Rate: $1.052 \times 10^{5} \mathrm{rad} / \mathrm{h}$ 
In this experiment, the data appears linear, but with an R-Square value lower than expected. As a result, I repeated the experiment. The data yields a dose rate of $1.052 \times 10^{5} \mathrm{rad} / \mathrm{h}$.

\subsection{Calibration of 774-A Source Centered Replicate}

\begin{tabular}{|c|c|c|c|c|c|c|}
\hline & Fricke Ref. & $\operatorname{Temp}\left({ }^{\circ} \mathrm{C}\right)$ & Position & Time (min) & Abs/min & $\mathrm{Rad} / \mathrm{h}$ \\
\hline & 0.173 & 25.7 & Center & 2.5 & . 0.0692 & $1.163 E+05$ \\
\hline 2 & 0.339 & 26.2 & Center & 5.0 & 0.0678 & $1.139 E+05$ \\
\hline 3 & 0.490 & 25.4 & Center & 7.5 & 0.065333 & $1.098 \mathrm{E}+05$ \\
\hline 4 & 0.655 & 24.0 & Center & 10.0 & 0.0655 & $1.100 E+05$ \\
\hline
\end{tabular}

Cobalt Source Calibration

Building 774 -A R e plic ate

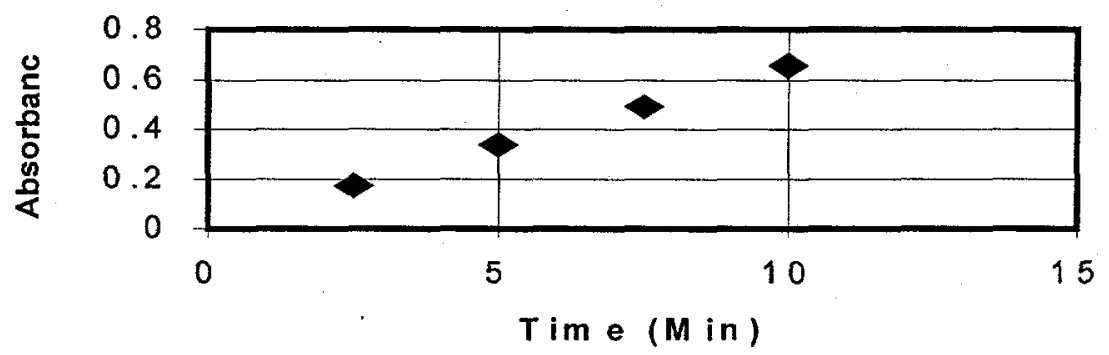

R-Square: 0.999668

Dose Rate: $1.073 \times 10^{5} \mathrm{rad} / \mathrm{h}$

In this experiment, the data again appears linear but with an R-Square within accepted parameters. (The author judged any value with an R-Square greater than 0.99 as acceptable.) The measurements indicate a dose rate of $1.073 \times 10^{5}$ $\mathrm{rad} / \mathrm{h}$.

\subsection{Calibration of 774-A Source Off-Center}

Cobalt c a libration source\# 2

W ith $N$ ylon $S$ upport

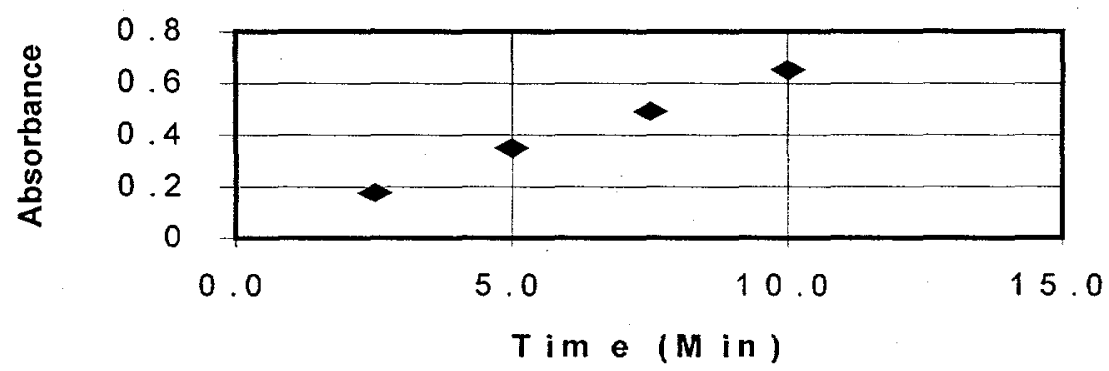




\begin{tabular}{|c|c|c|c|c|c|c|c|c|}
\hline \multicolumn{3}{|c}{ Time } & Water R. & Fricke R. Temp $\left({ }^{\circ} \mathrm{C}\right)$ & Position & Abs & Abs/min & Rad/h \\
\hline Fricke & n/a & 0.01 & n/a & n/a & n/a & n/a & n/a & n/a \\
\hline 1 & 2.5 & n/a & 0.180 & 26.0 & Off-Center & 0.180 & 0.072 & $1.210 \mathrm{E}+05$ \\
\hline 2 & 5.0 & n/a & 0.358 & 25.9 & Off-Center & 0.358 & 0.072 & $1.203 \mathrm{E}+05$ \\
\hline 3 & 7.5 & n/a & 0.590 & 25.3 & Off-Center & 0.590 & 0.079 & $1.322 \mathrm{E}+05$ \\
\hline .4 & 10.0 & n/a & 0.617 & 26.9 & Off-Center & 0.617 & 0.062 & $1.037 \mathrm{E}+05$ \\
\hline
\end{tabular}

\section{C a libration of $S$ ource \#2 O ff- Centered ( $A$ bsorbance vs. Tim e)}

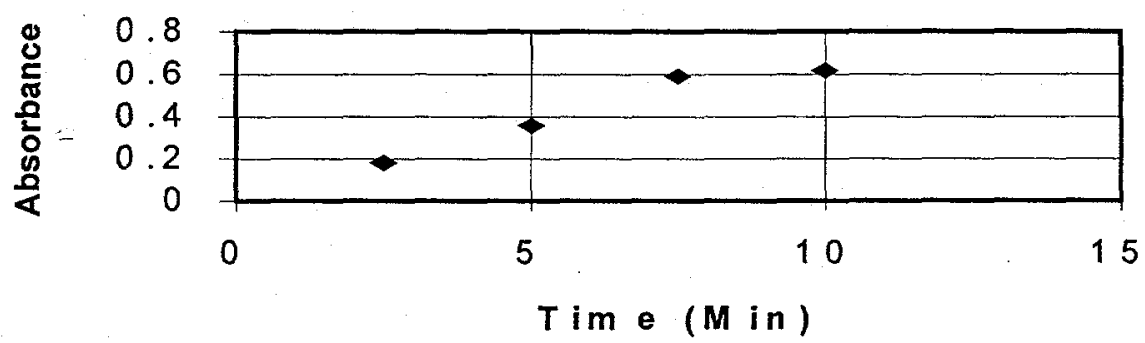

Dose Rate: $1.037 \times 10^{5} \mathrm{rad} / \mathrm{h}$

R-Square: 0.9293167

The resulting graph is not linear. The final point on the graph deviates significantly. As a result, the R-Square of this experiment was 0.929 , far lower then the acceptable value. The large error may have resulted from the source canister inadvertently revolving as personnel lowered it into the source. The rotation of the canister could have altered the placement of the graduated cylinder relative to the source, and thus affected the dose rate.

\subsection{Replicate Calibration of 774-A Source Uncentered}

\begin{tabular}{|r|r|r|r|r|r|r|}
\hline \multicolumn{2}{|c|}{ Time (min) } & Fricke Ref. Position & Temp $\left({ }^{\circ} \mathbf{C}\right)$ & Abs/min & Rad/h \\
\hline 1 & 2.5 & 0.194 & Off-Center & 26.5 & 0.0776 & $1.304 \mathrm{E}+05$ \\
\hline 2 & 5.0 & 0.398 & Off-Center & 26.4 & 0.0796 & $1.337 \mathrm{E}+05$ \\
\hline 3 & 7.5 & 0.537 & Off-Center & 26.5 & 0.0716 & $1.203 \mathrm{E}+05$ \\
\hline 4 & 10.0 & 0.685 & Off-Center & 26.3 & 0.0685 & $1.151 \mathrm{E}+05$ \\
\hline
\end{tabular}




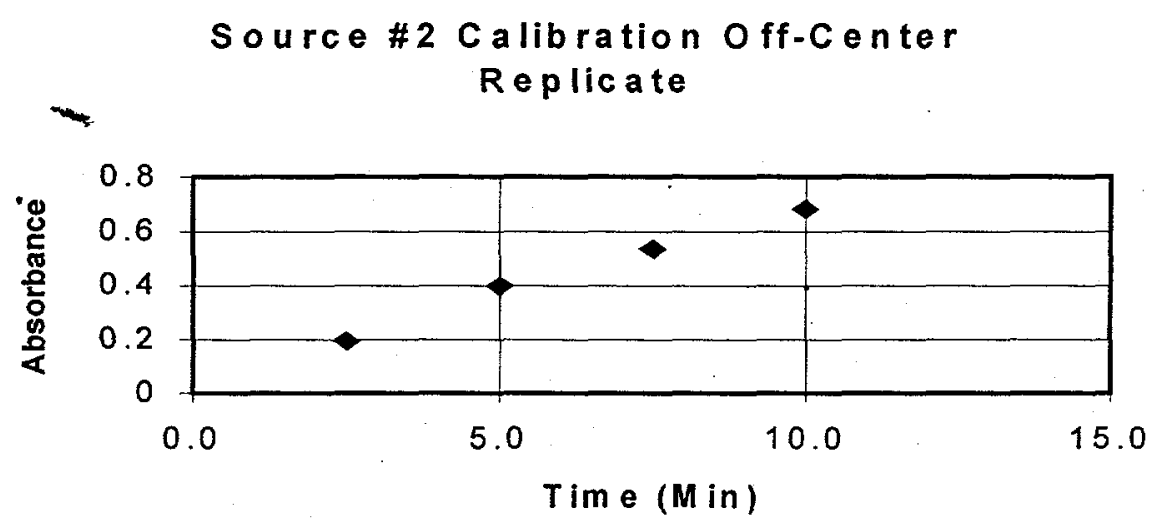

Dose Rate: $1.083 \times 10^{5} \mathrm{rad} / \mathrm{h}$

R-Square:-0.991924

The R-Square for the repeated experiment proved much larger and I accepted this dose rate as reliable for this configuration.

\subsection{Calibration of 773-A Source Centered}

\begin{tabular}{|r|r|r|r|r|r|r|r|}
\hline \multicolumn{2}{|c|}{ Time (s) } & \multicolumn{1}{c|}{ Time (min) } & \multicolumn{2}{c|}{ Fricke Ref. Position Temp $\left({ }^{\circ} \mathbf{C}\right)$} & Abs/min $\mathbf{R a d} / \mathbf{h}$ \\
\hline 1 & 19 & 0.32 & 0.205 & Center & 27.5 & 0.647 & $1.17 \mathrm{E}+06$ \\
\hline 2 & 35 & 0.58 & 0.345 & Center & 27.0 & 0.591 & $1.06 \mathrm{E}+06$ \\
\hline 3 & 48 & 0.80 & 0.456 & Center & 26.8 & 0.570 & $1.03 \mathrm{E}+06$ \\
\hline 4 & 63 & 1.05 & 0.583 & Center & 27.3 & 0.555 & $9.99 \mathrm{E}+05$ \\
\hline
\end{tabular}
C o b a it $S$ o u rce $773-A$
C e n tered C a libration

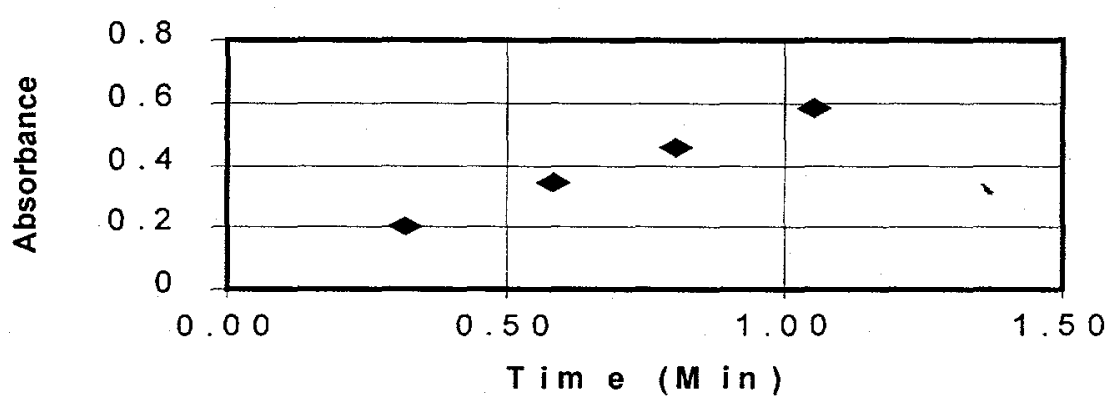

Dose Rate: $9.27 \times 10^{5} \mathrm{rad} / \mathrm{h}$

R-Square: 0.999935

The high R-Square for this experiment probably results because this cobalt source includes an automated design for lowering the graduated cylinder, rather than the manual design used in building 774-A. This method reduces the 
variances in speed for lowering the sample. A variance in speed results in a variance in the time the Dosimeter solution stays within the radiation field.

\subsection{Calibration of 773-A Source Off-Center}

\begin{tabular}{|r|r|r|r|r|r|r|r|}
\hline \multicolumn{2}{|c|}{ Time (s) } & Time (min) & Fricke Ref. Position Temp $\left({ }^{\circ} \mathrm{C}\right)$ & Abs $/ \mathrm{min}$ & Rad/h \\
\hline 1 & 19 & 0.32 & 0.232 & $\begin{array}{c}\text { Off- } \\
\text { Center }\end{array}$ & 27.5 & 0.732632 & $1.32 \mathrm{E}+06$ \\
\hline 2 & 35 & 0.58 & 0.383 & $\begin{array}{c}\text { Off- } \\
\text { Center }\end{array}$ & 27.0 & 0.656571 & $1.18 \mathrm{E}+06$ \\
\hline 3 & 48 & 0.80 & 0.515 & $\begin{array}{c}\text { Off- } \\
\text { Center }\end{array}$ & 26.8 & 0.64375 & $1.16 \mathrm{E}+06$ \\
\hline 4 & 63 & 1.05 & 0.651 & $\begin{array}{c}\text { Off- } \\
\text { Center }\end{array}$ & 27.3 & 0.62 & $1.12 \mathrm{E}+06$ \\
\hline
\end{tabular}

\section{Cobalt Calibration Inside Off- Centered}

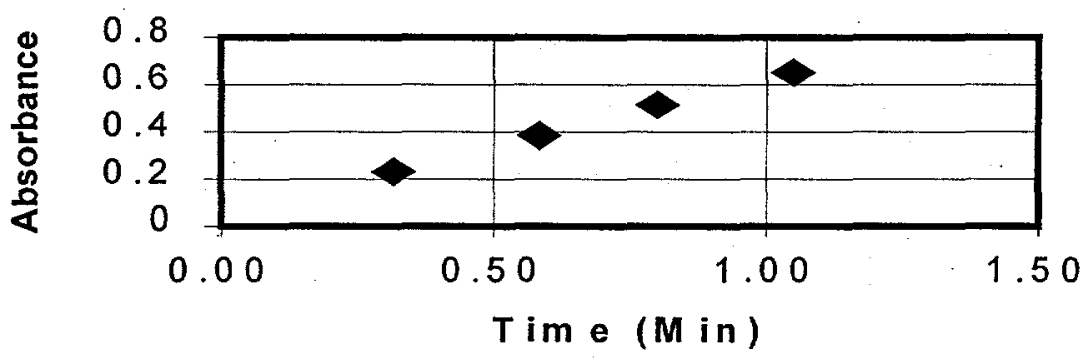

Dose Rate: $1.034 \times 10^{6} \mathrm{rad} / \mathrm{h}$

R-Square: 0.999603

The higher dose rate for the Off-Center test suggests a closer position to the cobalt source.

\section{Summary}

The data obtained from these Cobalt Source Calibration tests show the following.

- The experiments determined a dose rate of the \#2 cobalt source in Building 774-A of $1.073 \times 10^{5} \mathrm{rad} / \mathrm{h}$ (June 17, 1999). The dose rate of the Shepherd Model 109 Gamma cobalt source in Building 773-A measured $9.27 \times 10^{5}$ $\mathrm{rad} / \mathrm{h}$ (June 25,1999 ). These rates come from placing the graduated cylinder containing the dosimeter solution in the center of the irradiation chamber. 
- Two calibration tests in the 774-A source placed the graduated cylinder with the dosimeter solution off-center approximately 1.5 inches off in the axial direction. This movement of the sample reduced the measured dose rate $Q 22 \%$ from $1.083 \times 10^{5} \mathrm{rad} / \mathrm{h}$ to $1.073 \times 10^{5} \mathrm{rad} / \mathrm{h}$.

- A similar test in the cobalt source in 773-A placed the graduatêd cylinder approximately 2.0 inches off center in the axial direction. This change in position reduced the measured dose rate by $10.34 \%$ from $1.036 \times 10^{6} \mathrm{rad} / \mathrm{h}$ to $9.27 \times 10^{5} \mathrm{rad} / \mathrm{h}$.

- The use of some instrument to keep the calibration canister from rotating while lowering into the 774-A pit would help increase the accuracy of the results.

- The sources decrease in dose rate by a factor of approximately $0.8 \%$ every month. Hence, calibrations should occur on a monthly basis.

\subsection{Quality Assurance}

The procedures, measurement, and results with regard to this experiment are located in WSRC-NB-99-00150 lab notebook.

\subsection{Acknowledgements}

The author of this document would like to thank the following people who assisted in this experiment: Betty Croy, Lin Thacker, Kimberly Prettel, Charles Crawford, and Darrel D. Walker.

\subsection{References}

Bibler, Ned E. Calibration of Intense Co Gamma Ray Sources at the Savannah River Plant. May 1976. 
S. D. Fink

WSRC-TR-99-00303, Rev. 1

Page 10 of 10

DISTRIBUTION:

M. J. Barnes, 773-A

Chris Beam, 773-41A

S. D. Fink, 773-A

F..F. Fondeur, 773-A

D. T. Hobbs, 773-A

R. A. Peterson, 773-A

D. D. Walker, 773-A

STI, 703-43A

WPTS Files c/o Cathy Canada, 773-A 